\title{
Specifics of Modern Video Installations: Projection Mapping as a Form of Digital Art
}

\author{
Dokolova Alona Sergeevna \\ graduate student, \\ Kiev National University of Culture and Arts, Kiev, Ukraine
}

\begin{abstract}
The specifics of the development of projection mapping in historical retrospect and at the present stage are studied. The peculiarities of video mapping as a unique direction of audiovisual art of the end of the XX - the beginning of the XXI century are revealed. It is emphasized that as a phenomenon of digital art in which technology is organically combined with architecture, sculpture, theater, choreography, fashion or design, video mapping provides information about content, combining audiovisual elements and representing them with a projector. These elements emphasize the concept of the work of art, which builds the relationship between images, perception and space.
\end{abstract}

Key words: 3D-mapping, visual shows, video art, projections, multimedia technologies..

Постановка проблеми. 3D Video Mapping - (від англ. «video» - відео та «mapping» - відображення, проектування) - особливий напрямок аудіовізуального мистецтва, специфіка якого полягає у проекції на фізичний об'єкт навколишнього середовища з урахуванням його геометрії та місцеположення у просторі.

Використання 3D Video Mapping на початку XXI ст. поширюється на більшість галузей людської діяльності - промисловості, науки, культури та мистецтва, що актуалізує всебічне та грунтовне дослідження даного феномену.

Розробка принципів та використання художнього підходу до відеомеппінгу, 3 метою посилення моменту його видовищного, емоційного та інформаційного насичення, вимагає грунтовного наукового осмислення 3 позицій сучасного мистецтвознавства, оскільки відображає бачення соціокультурного та соціомистецького простору XXI ст.

Аналіз останніх досліджень і публікацій. Не зважаючи на швидку популяризацію відеомеппінгу в багатьох галузях людської діяльності, наукове осмислення даної проблематики знаходиться на стадії формування. У більшості наявних публікацій зарубіжних та вітчизняних дослідників відеомеппінг розглянуто як дигітальну технологію, призначену для прикрашання тривимірних поверхонь. Наприклад, С. Загребіна у науковій публікації «Відеомаппінг: до особливостей масового видовища XXI ст.» [1] розглядає тенденції розвитку масової видовищної культури та актуальні 
проблеми використання мультимедійних ресурсів у проведенні сучасних масових видовищ, а також визначає поняття «відеомеппінг», як одну 3 найактуальніших та популярних технологій мультимедійної культури; О. Наумова та С. Рудченко в статті «Відеомеппінг як відображення аудіовізуальної культури» [3] розглядають вплив нових інформаційних технологій та соціальних факторів на розвиток візуалізації; Р. Кеткніс у публікації «3D архітектурний відеомеппінг» [5] аналізує специфіку тривимірного архітектурного картографування як техніки відеопроекції, що зроблена за допомогою огляду обраного будинку, з метою реалізації ідеальної відповідності між його формами та зображенням, що проектується та ін.

Це актуалізує здійснення дослідження 3D відеомеппінгу як форми мистецтва, у контексті специфіки унікального середовища проектованих рухомих зображень інсталяційних художніх творів.

Дослідження спрямоване на розвиток вітчизняної фактологічної бази 3D відеомеппінгу.

Мета статті - виявити специфіку відеомеппінгу як унікального напрямку аудіовізуального мистецтва кінця XX - початку XXI ст.

У процесі дослідження відеомеппінгу як феномену цифрового мистецтва застосовано метод компаративного аналізу історії образотворчого мистецтва та історії техніки; системний підхід та метод структурного аналізу застосовані в процесі аналізу сучасних тенденцій в сценічному дизайні та встановленні їх зв'язку з розвитком мультимедійних технологій, що дозволило на основі синтезу різних знань описати феномен 3D-меппінгу як унікальне новаторське явище в сучасному сценічному мистецтві. Художня специфіка віртуального світу в статті виявлена на основі комплексного дослідження в галузях мистецтвознавства та естетики з одного боку та комп'ютерних технологій - 3 іншої.

XX ст. характеризується надзвичайною активізацією новаторських рухів у соціомистецькому просторі. Одним із найперспективніших в еволюціонуванні був синтез різних видів мистецтв в єдиний закінчений художній твір. Дослідники визначають дані процеси як змішані, мультимедійні [7]. Перші наукові дослідження даних процесів, як і виникнення термінологічного апарату мультимедійного мистецтва, датується серединою XX ст., проте з розвитком технологій та надзвичайно масштабною популяризацією, 
відбуваються характерні трансформаційні зміни - терміни починають втрачати власні першочергові значення. Зокрема, термін «мультимедіа» використовується в широкому спектрі галузей людської діяльності - в мистецтві, масових комунікаціях, інформатиці та ін., має різноманітні визначення, що відповідають галузевій специфіці.

Досягнення в галузі цифрових технологій здійснюють безпосередній вплив на сучасне мистецтво та культуру. Всесвітня мережа Інтернет стала не лише інструментом для масових комунікацій XXI ст., а й новаторським інструментом для сучасних художників і дизайнерів, що дозволило значно розширити межі творчості та розвинути нові форми аутентичного вираження.

Дигітальні технологій на сучасному етапі доцільно розглядати як додатковий мистецький інструмент у процесі створення новаторських творів мистецтва.

На думку дослідників, «цифрове мистецтво» визначається як форма мистецтва, що досліджує участь комп’ютерів, цифрових інструментів, технологій та цифрового інформаційного контенту як інструменту для концептуального створення, виробництва та експозиції творчих робіт [8, р. 605]. Процес створення в дигітальному мистецтві нерозривно пов'язаний з дизайном та розробкою комп’ютерних творів мистецтва.

Цифрове мистецтво надає підгрунтя для новаторських видів інструментарію, матеріалів та творів мистецтва, а також встановлює нові відносини між творцями, творами мистецтва та глядачем, що не мають аналогів. Якщо об'єкти мистецтва позиціонуються як прості символічні об’єкти, спрямовані на стимулювання емоцій, створені задля того, щоб дістатися до реципієнта через візуальні, аудіальні, тактильні відчуття та відображаються за допомогою фізичного матеріалу (паперу, каміння, дерева, металу та ін.), комбінуючи деякі взірці сприйняття для створення естетичної композиції, то об'єкти цифрового мистецтва за допомогою комп'ютерів та комп'ютерних артефактів маніпулюють цифровою кодованою інформацією та цифровими технологіями, інтенсивно досліджують комп'ютерне середовище, що відкриває необмежені можливості взаємодії, віртуалізації та маніпулювання інформацією. Дані цифрові художні об'єкти або артефакти (деякі з них є нематеріальними) - є результатом процесу художньої творчості, котрий у сукупності створює загальний комунікаційний та інформаційний простір. Оскільки інформаційний зміст (передбачене повідомлення) кожного артефакту 
позиціонується як центральна складова загального комунікаційного чи інформаційного простору, художні артефакти визначаються як інформаційні об'єкти [8, p. 605].

А. Маркос визначає комп’ютерне середовище як набір цифрових технологій (від цифрових інформаційних форматів, інфраструктур до інструментів обробки), що в сукупності доцільно розглядати як безперервне художнє середовище, що використовується художниками для створення дигітальних артефактів [9, p. 101].

Відповідно, інтерактивні інсталяції, віртуально створені середовища, цифрова анімація, відео та пов'язана з цим розробка програмного забезпечення може розглядатися в межах дигітального мистецтва [6].

За допомогою комп’ютерної віртуальної реальності здійснюється перехід внутрішньої інтуїтивної та інтелектуальної рефлексії суб'єкта в розгорнуті предметночуттєві образи та дії $[4$, с. 6$]$.

Цифрове мистецтво стало зв'язуючою ланкою не лише сучасного мистецтва, а й для електронних медіа, діяльність яких забезпечується співробітництвом мистецтва, науки та техніки.

3. Сагламтімур наголошує, що «розвиток різноманітних інструментів та інтерфейсів, таких як комп’ютери, фотографія, відео, Інтернет, сканери, масштабатори та ін., сформувало основу дигітальних технологій. Окрім того, програмне забезпечення, розроблене для обробки фотографій, цифрового малювання, комп’ютерних зображень та анімації, широко використовується в процесі створення цифрових творів мистецтва» [11, p. 220]. Показ творів мистецтва, створених за допомогою даних інструментів та програмного забезпечення, переважно проектується на поверхню (за допомогою проектора).

За дигітальної доби проекція стає важливим інструментом для презентування та комунікації, використовується для відображення цифрових інсталяцій та їх перегляду.

Інсталяція - це вид мистецтва, представлений творами архітекторів, скульпторів та художників, які працюють як у приміщенні, так і на відкритому повітрі, котре займає певний об’єм.

У процесі створення художніх об’єктів використовуються виражальні засоби різноманітних видів мистецтва - графіки, живопису, скульптури, інсталяції, монументального і декоративно-прикладного мистецтва та ін., а також застосовуються 
сучасні технічні засоби. Їх інтегрування в мистецьку практику $є$ актуальним та своєчасним завданням, оскільки сприяє досягненню стабільніших якостей навколишнього середовища та розвитку художньо-естетичних поглядів глядача [2, с. 8].

Інсталяційне мистецтво зародилося в 60-х рр. XX ст. завдяки таким художнім рухам як футуризм та дадаїзм, а антихудожній рух інтегрував у процес створення мистецтва аудиторію та предмети. Відеоінсталяції, відповідно, є формами відеоарту.

Одними з лідерів створення мистецьких шедеврів, в яких було поєднано аудіо та відео, були Д. Пайк та М. Дюшан - їх експериментальні постановки позиціонуються як новаторські приклади відео- та інсталяційного мистецтва в сучасну дигітальну добу.

Б. Екім акцентує, що нові медіа кінця ХХ ст. представляють собою композицію відеоарту та його гібридів [6].

На сучасному етапі відеомистецтво може бути створене та показане на екрані шляхом додавання різноманітних інтерфейсів та інструментів в якості частини постановки або інсталяцій. Відеоінсталяції початку XXI ст., відомі також як відеомеппінг, формують відношення між простором (зовнішні чи внутрішні стіни будівель, сценічний простір та ін.) та матеріалами, котрі відеолізуються і відображаються на певній поверхні. Відповідно до специфіки, простір відіграє активну роль в процесі демонстрування та визнання новаторських мистецьких форм у публічному просторі.

Відеомеппінг - інноваційний метод відеопроекції, що використовується для перетворення практично будь-якої поверхні на динамічний відеодисплей, метою якого є створення фізичної ілюзії зображення, шляхом комбінування аудіовізуальних елементів.

Більшість картографічних проектів (відеопроекції) використовується в дизайнерському оформленні показів мод, корпоративних урочистостей, концертів та театральних вистав (зазвичай поєднується 3 виконавськими видами мистецтва). Тенденціями, що швидко популяризуються у світі є відеопроекції на архітектурних спорудах та історичних будівлях, з метою охоплення більш широкої аудиторії.

Останні розробки в галузі технологій відеопроекції здатні віднайти новаторські способи вираження творчості та аудіовізуальних художніх творів на нових поверхнях.

Відповідно до специфіки дигітального мистецтва, використання даної мистецької форми класифікується дослідниками водночас як «інструмент» та «середовище» [10, р. 8]. На основі даної класифікації, у проектах відеомеппінгу використовуються технології 
в якості «інструменту» для складання та редагування програм створення рухомої графіки та зображень, а також для репрезентування створених зображень глядачу.

Відеомеппінг - це метод передачі відео (за стандартним відеопроектором) на тривимірні об'єкти, а також коригування та маскування зображення таким чином, щоб воно відповідало формі цільового об'єкту. У результаті відео вже не позиціонується як площинний квадрат на стіні, а стає об’єктом простору - «анімованою скульптурою» [6]. Ця 2D графіка стає 3D графікою, щойно починається процес взаємодії з поверхнею, що передає глядачу повідомлення, використовуючи аудіовізуальні елементи у власній інфраструктурі.

Методом вивчення цифрових технологій розробляються концепції, що реалізуються за допомогою новаторського інструментарію - мультимедіа, віртуальної реальності, комп'ютерного бачення, дигітальної музики, звуку та ін. Кодована інформація використовується для створення інсталяцій та цифрових артефактів - вона доставляється з використанням різноманітних комунікаційних інфраструктур, таких як Інтернет, презентаційні пристрої та сховище даних. Більшість технічних аспектів для додатків відображення відео поділяються на кілька підкатегорій:

- для графіки руху (створення зображення для аудіовізуальної комунікації 3 використанням різноманітних візуальних ефектів та дигітальних артефактів);

- для звукового дизайну (доповнення та підтримка звуковими елементами візуального шоу);

- для відео в реальному часі (допомога художнику, який відповідає за проектування, зокрема, одночасне включення доповнення до відеоінсталяцій);

- для проекції.

Безпосередній вплив на дигітальне мистецтво здійснює мистецтво концептуальне - художній рух, заснований на «концепції» або «ідеї». Концепція є найважливішим аспектом для композиції художнього твору, що сприяє посиленню уваги глядача завдяки поєднанню мистецтва і технології. Таким чином, доцільно позиціонувати всі продукти, що формуються в межах цифрового мистецтва як «комп’ютерні твори мистецтва». Процес творчо-технічної реалізації розробленої концепції визначає відмінності всіх продуктів, включно з розробкою нового типу технологій, інструментарію та зв'язку (мережею, що пов'язує твори мистецтва та глядача). Отже, відеомеппінг - найновіший 
метод аудіовізуальної вистави, розроблений з метою посилення уваги та відчуттів глядача, шляхом використання відеоінсталяцій в межах концепції для суспільного простору.

Висновок. Протягом останнього десятиліття розвиток цифрових технологій значно посприяв створенню та еволюціонуванню комп'ютерних творів мистецтва відеоінсталяцій, відомих як 3D videomepping. Відеомеппінг - новий метод проектування, що використовується для перетворення об'єктів, нерідко неправильних форм, на поверхні відображення. Цей режим проектування охоплює тривимірні поверхні, від невеликих об'єктів до великих будівель, з цифровими рухомими зображеннями. Шляхом накладання рухомих зображень проекційне відображення створює просторово-часові шари на статичний об’єм (наприклад, інсталяцій з рухомими зображеннями, в процесі створення яких використовується проекційне кадрування).

Як феномен дигітального мистецтва в якому технології органічно поєднано 3 архітектурою, скульптурою, театром, хореографією, модою чи дизайном, відеомеппінг подає інформацію про контент, поєднуючи аудіовізуальні елементи та репрезентуючи їх за допомогою проектора. Ці елементи підкреслюють концепцію художнього твору, що будує відносини між зображеннями, сприйняттям та простором.

Перспективи подальших досліджень полягають в комплексному мистецтвознавчому аналізі відеопроекційного меппінгу як технології сучасного мультимедійного мистецтва.

\section{References}

1. Zagrebina, S. A. (2016). Video mapping: to the peculiarities of a 21 st century mass show Bulletin of Humanitarian Education, no. 1, pp. 112-115.

2. Enyutina, E. D. (2015). Features of the artistic approach to the formation of the modern urban environment: abstract dis. Cand. architecture: 05.23.20 / Nizhny Novgorod State University of Architecture and Civil Engineering. Nizhny Novgorod.

3. Naumova, O. G., Rudchenko, S. K. (2018). Video mapping as a reflection of audiovisual culture. Problematic field of media education, no. 2 (28), pp. 72-79.

4. Yatsyuk, O. G. (2009). Multimedia technologists in the design culture of design: humanitarian aspect: abstract of thesis. Doctor of Arts: 17.00.06 / All-Russian Scientific Research Institute of Technological Aesthetics. Moscow.

5. Catanese, R. (2013). 3D architectural videomapping. International Archives of the Photogrammetry, Remote Sensing and Spatial Information Sciences, Volume XL-/W2, 2013 XXIV International CIPA Symposium, 2- 6 September 2013, Strasbourg, France, pp. 165-169. 
6. Ekim, B. (2011). A video projection mapping conceptual designand application: Yekpare. The Turkish Online Journal of Design, Art and Communication - TOJDAC, Vol. 1, Issue 1. URL :

https://www.academia.edu/534617/A_Video_Projection_Mapping_Conceptual_Design_and Application_YEKPARE.

7. Kossev, S. Multimedia as a form of interaction between art and technology. URL: https://www.academia.edu/33697191/MULTIMEDIA_AS_A_FORM_OF_INTERACTION_ BETWEЕN_ART_AND_TЕСНNOLOGY_МУЛТИМЕДИЯТА_КАТО_ФОРМА_НА_ВЗА ИМОДЕЙСТВИЕ_МЕЖДУ_ИЗКУСТВОТО_И_ТЕХНОЛОГЙЯТА.

8. Marcos, F., Branco, P. S., Zagalo, N. T. (2009). The Creation Process inDigital Art. Handbook of Multimedia For Digital Entertainment \& Arts. Ed. BorkoFuhrt. New York : Springer Science and Business Media, pp. 601-615.

9. Marcos, A. (2007). Digital Art: When artistic and cultural muse and computer technology merge. IEEE Computer Graphics and Applications, no. 5 (27), pp. 98-103.

10. Paul, C. (2002). Digital Art. London: Thames and Hudson.

11. Saglamtimur, Z. (2010). Digital Art. Anadolu University Journal of Social Sciences, no. 10 (3), pp. 213-238.

\section{$\underline{\text { Translation of references to original language }}$}

\section{Jimepamypa}

1. Загребина, С. А. (2016). Видеомаппинг: к особенностям массового зрелища XXI в. Вестник гуманітарного образования. № 1. С. 112-115.

2. Енютина, Е. Д. (2015). Особенности художественного подхода к формированию современной городской среды : автореферат дис. канд. архитектуры : 05.23 .20 / Нижегородский государственный анхитектурно-строительный университет. Нижний Новгород.

3. Наумова, О. Г., Рудченко, С. К. (2018). Видеомэппинг как отражение аудиовизуальной культуры. Проблемное поле медиаобразования. № 2(28). С. $72-79$.

4. Яцюк, О. Г. (2009). Мультимедийные технологи в проектной культуре дизайна: гуманитарный аспект : автореферат дис. доктора искусствоведения : 17.00 .06 / Всероссийский научно-исследовательский інститут техныческой естетики. Москва.

5. Catanese, R. (2013). 3D architectural videomapping. International Archives of the Photogrammetry, Remote Sensing and Spatial Information Sciences, Volume XL-/W2, 2013 XXIV International CIPA Symposium, 2- 6 September 2013, Strasbourg, France, pp. 165-169.

6. Ekim, B. (2011). A video projection mapping conceptual designand application: Yekpare. The Turkish Online Journal of Design, Art and Communication - TOJDAC. Vol. 1. Issue 1. URL https://www.academia.edu/534617/A_Video_Projection_Mapping_Conceptual_Design_and Application_YEKPARE. 
7. Kossev, S. Multimedia as a form of interaction between art and technology. URL : https://www.academia.edu/33697191/MULTIMEDIA_AS_A_FORM_OF_INTERACTION_ BETWEEN_ART_AND_TECHNOLOGY_МУЛТИМЕДИЯТА_КАТО_ФОРМА_НА_ВЗА ИМОДЕЙСТВИЕ_МЕЖДУ_ИЗКУСТВОТО_И_ТЕХНОЛОГИЯТА.

8. Marcos, F., Branco, P. S., Zagalo, N. T. (2009). The Creation Process inDigital Art. Handbook of Multimedia For Digital Entertainment \& Arts. Ed. BorkoFuhrt. New York : Springer Science and Business Media, pp. 601-615.

9. Marcos, A. (2007). Digital Art: When artistic and cultural muse and computer technology merge. IEEE Computer Graphics and Applications. № 5 (27). pp. 98-103.

10. Paul, C. (2002). Digital Art. London: Thames and Hudson.

11. Saglamtimur, Z. (2010). Digital Art. Anadolu University Journal of Social Sciences. № 10 (3). pp. 213-238. 